\title{
The Comparative Immunomodulatory Effects of $\beta$-Glucans from Yeast, Bacteria, and Mushroom on the Function of Macrophages
}

\author{
Seon-A Jang ${ }^{1}$, Sulkyoung Park ${ }^{1}$, Jung-Dae Lim ${ }^{1}$, Se-Chan Kang ${ }^{2}$, \\ Kwang-Hee Yang ${ }^{3}$, Suhkneung Pyo $^{4}$, and Eun-Hwa Sohn ${ }^{1 \dagger}$ \\ ${ }^{1}$ Department of Herbal Medicine Resource, Kangwon National University, Institute of \\ Bioscience and Biotechnology, Gangwon 245-711, Korea \\ ${ }^{2}$ Department of Natural Medicine Resources, Semyung University, Chungbuk 390-711, Korea \\ ${ }^{3}$ Radiation Health Research Institute, Korea Hydro \& Nuclear Power Co., Ltd, Seoul 132-703, Korea \\ ${ }^{4}$ Division of Immunopharmacology, College of Pharmacy, Sungkyunkwan University, Gyeonggi 440-746, Korea
}

\begin{abstract}
The comparative immunomodulatory effects of $\beta$-glucans isolated from mushroom fungi (Coriolus versicol), yeast (Saccharomyces cerevisiae) and bacteria (Agrobacterium) on the major functions of macrophages were evaluated. As parameters of macrophage functions, we examined tumoricidal activity, phagocytosis, nitric oxide (NO) production, and the induction of inducible NO synthetase (iNOS) in RAW264.7 cells, following treatments with $\beta$-glucans from the three different sources. The results indicated that all $\beta$-glucan treatments significantly induced tumoricidal activity in the RAW264.7 cells, with a remarkable effect shown by the beta-glucan from Agrobacterium at a concentration of $10 \mu \mathrm{g} / \mathrm{mL}$. There was also a significant increase in iNOS-NO system activity in macrophages treated with $\beta$-glucans extracted from yeast; however, iNOS-NO system activity was not markedly changed by the treatment of $\beta$-glucans from $C$. versicolor mushroom fungi or Agrobacterium. Furthermore, the $\beta$ glucans from $C$. versicolor had a significant phagocytotic effect at concentrations of 1,10 , and $100 \mu \mathrm{g} / \mathrm{mL}$. Taken together, the present data suggest that these $\beta$-glucans, isolated from three different sources, have different effects on macrophage function, and therefore, may have different clinical uses in different for various types of diseases.
\end{abstract}

Key words: $\beta$-glucan, Corious versicolor, Saccharomyces cerevisiae, Agrobacterium, macrophages

\section{INTRODUCTION}

$\beta$-Glucans are naturally occurring $(1 \rightarrow 3)-\beta$-D-linked polymers of glucose, which are found in the cell walls of certain pathogenic bacteria and fungi (1-3). $\beta$-Glucans can be isolated from almost every species of yeast. In addition, they can be isolated from bacteria, mushrooms, algae, and cereal grains. The structure of $\beta$-glucans depends on both the source and type of isolation. Different physicochemical parameters such as solubility, primary structure, molecular weight, and branching play a role in the biological activities of $\beta$-glucans (4). $\beta$-Glucans are widely used as dietary supplements and in anticancer therapy, with well-established stimulating effects on the immune defense system. Many studies have demonstrated that $\beta$-glucans, either in particulate or soluble forms, have stimulating effects on innate immune cells [macrophages, neutrophils (PMN), and natural killer (NK) cells], on antibacterial and anti-tumor activities, and on the production of cytokines $(5,6)$.

Macrophages are considered important components of innate immune responses against bacterial infections and cancer $(7,8)$. This host wide system of macrophages undergoes four developmental changes in response to various signals, and these developmental changes are accompanied by a gain of some functions and a loss of other functions. According to their activation status, the cells in each corresponding stage are called resident-, inflammatory- (or responsive), primed-, or fully activatedmacrophages in murine systems, respectively $(9,10)$. It is well known that exposure to IFN- $\gamma$ and LPS, in vitro, causes a drift of inflammatory macrophages into the fully activated stage by acquiring the capacity to kill tumor cells. During development into the next stage, macrophages undergo an induction of phagocytic activity and have an increase in the secretion of various materials such as cytokines and reactive intermediates to carry out nonspecific immune responses $(9,11)$. In particular, there has been great interest in the reactive nitrogen intermediate, nitric oxide (NO), which is considered to be a central molecule in the regulation of the immune response to tumors, owing to its cytotoxic effects (12-14).

${ }^{\dagger}$ Corresponding author. E-mail: ehson@kangwon.ac.kr

Phone: +82-33-570-6492, Fax: +82-33-570-6499 
It is also known that inducible nitrogen synthase (iNOS) is expressed in many different cell types and the level of iNOS is proportional to the level of NO (14). In the present study, we examined the comparative immunomodulatory effects of $\beta$-glucans from yeast, bacteria, and mushroom sources on the tumoricidal activity, phagocytic activity, and iNOS-NO system activity of macrophages.

\section{MATERIALS AND METHODS}

Preparation of $\beta$-glucans from bacteria, yeast, and mushrooms

Bacterial $\beta$-glucans (MW $3 \times 10^{5} \quad$ Da) from Agrobacterium species (above $85 \%$ purity) were obtained from DMJ Biotech Corp. (Yeongi-gun, Chungcheongnam-do). The yeast $\beta$-glucans originated from Saccharomyces cerevisiae (minimum purity 98\%) and were purchased (G5011; Sigma, USA). The mushroom $\beta$-glucans were isolated from Coriolus versicolor. The process for isolating and purifying the water-soluble glucans from C. versicolor included hot water extraction, filtration, solvent precipitation, dialysis, and freezedrying. The acidic fractions of the polysaccharide were separated from crude polysaccharides by DEAE-cellulose anion exchange chromatography at $0.7 \mathrm{M} \mathrm{NaCl}$. The molecular weight of the proteo-heteroglycan after Sepharose CL-4B gel filtration chromatography was approximately $750 \mathrm{kDa}$. This product was shown to contain an $85 \%$ purity level.

\section{Cell culture}

The mouse monocyte/macrophage cell line, RAW264.7, was maintained in RPMI 1640 medium (Cambrex, Walkersville, MD) supplemented with $10 \%$ fetal bovine serum (Cambrex) and $2 \%$ penicillin/streptomycin (Cambrex) and was incubated at $37^{\circ} \mathrm{C}$ in $5 \% \mathrm{CO}_{2}$.

\section{MTT assay for cell viability}

Cell viability was determined by a 3-(4,5-dimethylthiazol-2-yl)-2,5-diphenyltetrazolium bromide (MTT) assay as described previously (15). Briefly, the cells were seeded in 96-well plates at a density of $5 \times 10^{4}$ cells per well and incubated with various concentrations of two reagents for $24 \mathrm{hr}$. The cells were washed once with D-PBS, and $200 \mu \mathrm{L}$ of MTT solution $(25 \mu \mathrm{g} / \mathrm{mL}$ in media) was added to each well. After incubation at $37^{\circ} \mathrm{C}$ under $5 \% \mathrm{CO}_{2}$ for $4 \mathrm{hr}$, the MTT solution was carefully discarded and the formazan blue crystals formed by the reduction of MTT were dissolved in $150 \mu \mathrm{L}$ of DMSO. The amount of formazan was determined by absorbance at $540 \mathrm{~nm}$ using a microplate reader (Menlo Park, CA).

\section{NBT assay for phagocytosis}

Phagocytosis was measured by a nitro blue tetrazolium (NBT) reduction assay as described previously (16). The cells were seeded in 96-well plates at a density of $5 \times 10^{4}$ cells per well and incubated with various concentrations of two reagents for $24 \mathrm{hr}$. The cultured media was then removed, and $50 \mu \mathrm{L}$ of zymosan $\left(5 \times 10^{6}\right.$ particles $\left./ \mathrm{mL}\right)$ and $0.6 \mathrm{mg} / \mathrm{mL}$ of NBT were added to each well. After an additional incubation for $1 \mathrm{hr}$, the cells were washed twice with cold D-PBS and the optical density of the reduction product of NBT (a purple insoluble formazan) was determined at $540 \mathrm{~nm}$ using a microplate reader.

\section{Macrophage-mediated tumoricidal activity}

The assay for macrophage cytotoxicity was based on an assay described elsewhere (8). Briefly, the macrophages $\left(1 \times 10^{5}\right.$ cells/well $)$ from mice were first incubated in either medium alone or in medium supplemented with various doses of two reagents for $24 \mathrm{hr}$ in 96-well plates. The macrophages were then washed with RPMI-FBS to remove the two reagents and co-incubated with B16 melanoma cells $\left(1 \times 10^{4}\right.$ cells/well; effector : target cell ratio of 10:1). After $24 \mathrm{hr}$, the plates were stained with crystal violet containing $10 \%$ formaldehyde for $15 \mathrm{~min}$. The absorbance of each well was determined at $540 \mathrm{~nm}$ using a Molecular Devices microplate reader (Menlo Park, CA, USA). Cytotoxic activity was expressed as the percentage of tumor cytotoxicity by the following formula: $[1-\{\mathrm{OD}$ of (target cells + macrophages)-OD of macrophages $\} / O D$ of target cells] $\times 100$, where the OD of target cells is the optical density of B16 melanoma cells and the OD of macrophages is the optical density of the macrophages.

\section{Nitrite determination}

The cells were treated with various concentrations of two reagents for $24 \mathrm{hr}$ and the accumulation of nitrite in the culture supernatant was measured as described by Ding et al (17). Here, $100 \mu \mathrm{L}$ aliquots of the culture supernatant were mixed with an equal volume of Griess reagent (1:1 mixture of naphthylethylenediamine dihydrochloride and $1 \%$ sulphanilamide in $\left.5 \% \mathrm{H}_{3} \mathrm{PO}_{4}\right)$ and incubated at room temperature for $10 \mathrm{~min}$. The nitrite concentration was calculated from a $\mathrm{NaNO}_{2}$ standard curve.

\section{Westem blot analysis}

The amount of iNOS was measured by Western blot analysis. After $6 \mathrm{hr}$ of incubation with or without two reagents, the cells in 6-well plates were lysed in sodium dodecylsulfate polyacrylamide gel electrophoresis buffer. The protein concentrations were measured using the DC Protein Assay (Bio-Rad Laboratories, Hercules, CA, 
USA). Twenty micrograms of each sample were electrophoresed on $10 \%$ sodium dodecylsulfate polyacrylamide gel electrophoresis gels and transferred to Hybond-ECL nitrocellulose membranes (Amersham Biosciences, Piscataway, NJ, USA). The membranes were blocked with 5\% skim milk in Tris-buffered saline/non-fat Tween for $1 \mathrm{hr}$. The membranes were incubated with primary antibody against iNOS for $24 \mathrm{hr}$. They were then washed with Tris-buffered saline/non-fat Tween once for $15 \mathrm{~min}$ and three times for $5 \mathrm{~min}$, and were incubated with secondary ALP-conjugated anti-rabbit antibody for $1 \mathrm{hr}$. The membranes were then washed again as described above. Autoradiography was carried out using an enhanced chemiluminescence kit (Amersham Bioscience).

\section{Statistical analysis}

The data are presented as means \pm SEM The statistical differences between groups were determined using one-way analysis of variance (ANOVA) with a Dunnett's t-test. The significant values are represented by an asterisk $\left({ }^{*} \mathrm{p}<0.05,{ }^{* *} \mathrm{p}<0.01\right)$.

\section{RESULTS}

\section{Effects of $\boldsymbol{\beta}$-glucans on cell viability}

To determine the optimal concentrations of the $\beta$ -glucans from yeast, bacteria, and mushrooms for their immuno-stimulating activity in macrophages, we evaluated the cell viability or proliferation effects of the various $\beta$-glucans in RAW264.7 cells. None of the $\beta$-glucans had effects on cell viability or cell proliferation (data not shown). Therefore, in all subsequent experiments, the $\beta$-glucans were used at concentrations of 1 to 100 $\mu \mathrm{g} / \mathrm{mL}$ for $24 \mathrm{hr}$.

\section{The effects of $\beta$-glucans on phagocytosis}

Phagocytosis is the primary activity of macrophages and is responsible for a diverse range of antimicrobialand cytotoxic-activities, including respiratory burst, the secretion of inflammatory mediators, and antigen presentation. In this study, we examined the effects of three $\beta$-glucans on the phagocytosis of macrophages. As shown in Fig. $1 \mathrm{~A}$ and $\mathrm{B}$, the yeast $\beta$-glucans increased the phagocytotic activity of the macrophages at $100 \mu \mathrm{g} /$ $\mathrm{mL}$, whereas the bacterial $\beta$-glucans increased phagocytotic activity at a lower concentration of $1 \mu \mathrm{g} / \mathrm{mL}$, and the treatment of the mushroom $\beta$-glucans increased phagocytotic activity in a dose-dependent manner (Fig. 1C).

\section{The effects of $\beta$-glucans on tumoricidal activity in macrophages}

To examine whether the three $\beta$-glucan treatments would stimulate tumoricidal activity in macrophages against target tumor cells, the macrophages were co-cul-
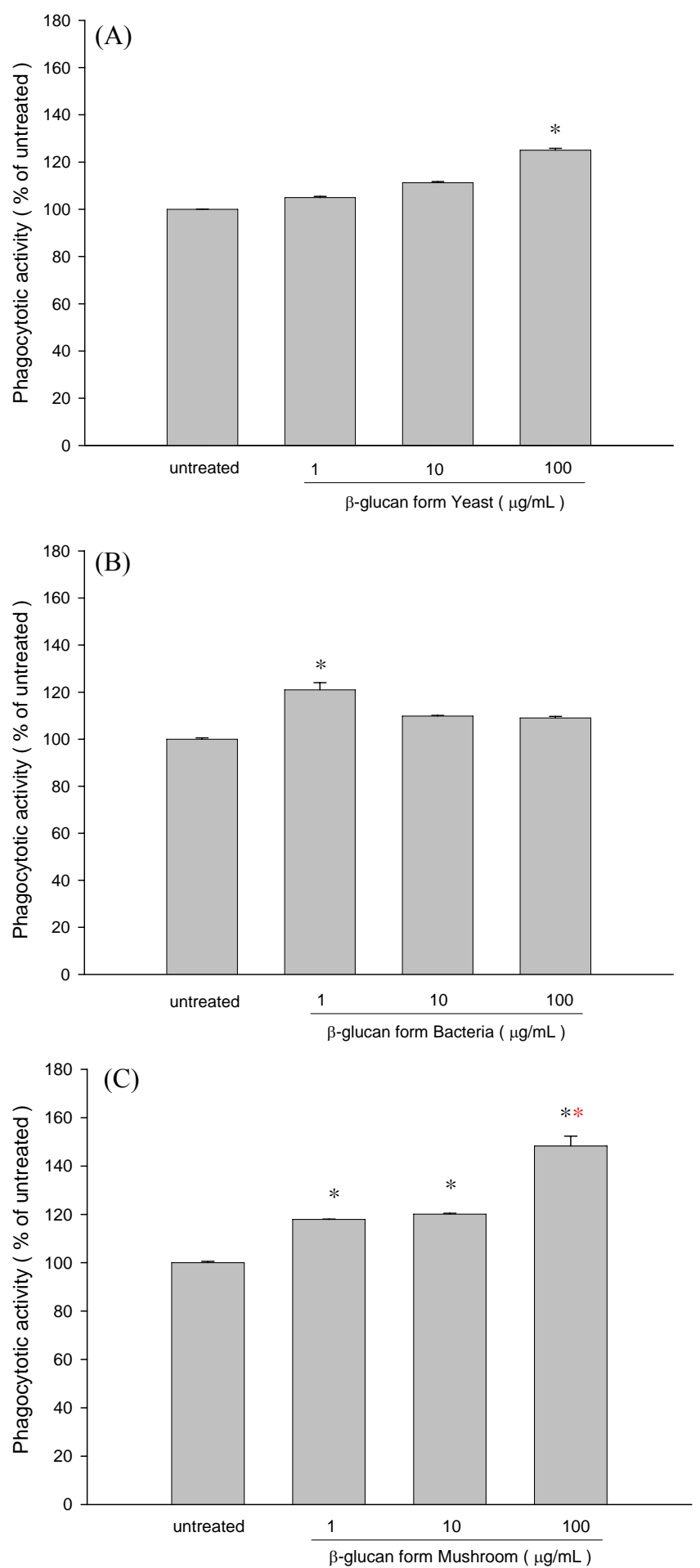

Fig. 1. Effects of $\beta$-glucans from yeast (A), bacteria (B), and mushrooms (C) on phagocytosis in RAW264.7 cells. The cells were treated with the three types of $\beta$-glucans for $24 \mathrm{hr}$, respectively, and then incubated with media containing zymosan $\left(1 \times 10^{6}\right.$ particles $\left./ \mathrm{mL}\right)$ and NBT $(0.6 \mathrm{mg} / \mathrm{mL})$ for 1 hr. Formazan formation was measured at $540 \mathrm{~nm}$. The data represent the mean \pm SEM of quadruplicate experiments. $\mathrm{p}<0.05,{ }^{* *} \mathrm{p}<0.01$; significantly different from the control (no treatment).

tured with B16 cells for $24 \mathrm{hr}$. The B16 tumor cells 
were used as a target since they are known to be either TNF- $\alpha$ or NO sensitive. As shown in Fig. 2, all $\beta$-glucan treatments increased the tumoricidal activity of the macrophages. The bacterial $\beta$-glucans enhanced tumoricidal activity at $1,10,100 \mu \mathrm{g} / \mathrm{mL}$; however, the 100 $\mu \mathrm{g} / \mathrm{mL}$ treatment had a lower stimulating effect than the 1 and $10 \mu \mathrm{g} / \mathrm{mL}$ treatments (Fig. 2B). These results were similar to those for phagocytotic activity (Fig. 1B).

\section{The effects of $\beta$-glucans on nitric oxide production and iNOS gene expression}

$\mathrm{NO}$ is related to the cytotoxic ability of macrophages against a variety of tumors and microorganisms, and it is produced in high amounts by iNOS in activated macrophages $(13,14)$. We, therefore, examined the dose-dependent effects of the $\beta$-glucans from different sources at various concentrations on NO production and iNOS gene expression (Fig. 3). As shown in Fig. 3A and B, iNOS-NO system activity was significantly increased by the yeast $\beta$-glucans. Moreover, there was a significant increase in NO production by the bacterial $\beta$-glucan treatment at $100 \mu \mathrm{g} / \mathrm{mL}$, and it also increased iNOS expression at 1, 10, and $100 \mu \mathrm{g} / \mathrm{mL}$ (Fig. 3C, Fig. 3D). The mushroom $\beta$-glucans increased iNOS-NO system activity at the lower concentration of $1 \mu \mathrm{g} / \mathrm{mL}$, but iNOS expression was only slightly increased at the concentration of $10 \mu \mathrm{g} / \mathrm{mL}$ (Fig. 3E, Fig. 3F).

\section{DISCUSSION}

It is common knowledge in the scientific community that $\beta$-glucans are the most powerful known immune stimulants, and are very powerful antagonists to both benign and malignant tumors; they also lower cholesterol and triglyceride levels, normalize blood sugar levels, heal and rejuvenate the skin, and have various other benefits (18). In the present study, our data demonstrate that $\beta$-glucans from yeast, bacteria, and mushroom have differential immunomodulatory effects on tumoricidal activity, phagocytic activity, and iNOS-NO system activity in RAW264.7 cells. These differential effects might be due to differences in their $\beta$-glucan structures. Previous$1 \mathrm{y}$, it was shown that $\beta$-glucans derived from various sources have certain structural differences (19). $\beta$ Glucans are a heterogeneous group of glucose polymers, consisting of a backbone of $\beta(1,3)$-linked $\beta$-D-glucopyranosyl units with $\beta(1,6)$-linked side chains of varying distribution and length. These structural differences resulting from variations in the side chains might be implicated in the activity of $\beta$-glucans (20). Bacterial $\beta$ -glucans are primarily linear with large regions of $\beta(1,4)$ linkages separating shorter stretches of $\beta(1,3)$ structures.
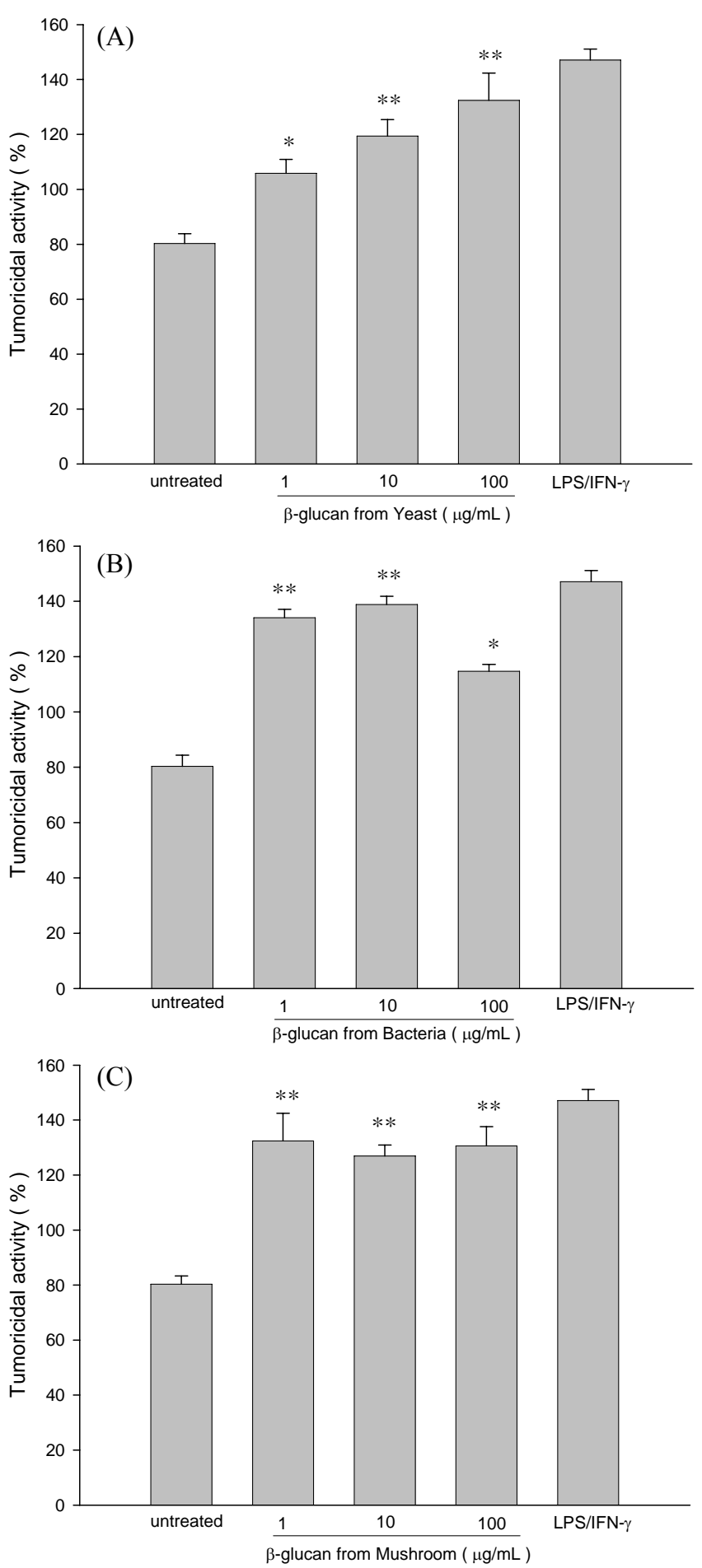

Fig. 2. Effects of $\beta$-glucans from yeast (A), bacteria (B), and mushrooms (C) on tumoricidal activity in RAW264.7 cells. The cells were co-cultured with target cells (B16) at an effector/ target ratio of 10:1 for $24 \mathrm{hr}$ in the presence or absence of various doses of the three types of $\beta$-glucans, respectively. Macrophage tumoricidal activity was calculated as described in the Material and Methods. The formation of formazan by the macrophages was determined by MTT assay. Cell density was measured at $540 \mathrm{~nm}$. The data represent the mean \pm SEM of quadruplicate experiments. ${ }^{*} \mathrm{p}<0.05,{ }^{* *} \mathrm{p}<0.01$; significantly different from the control (no treatment). 


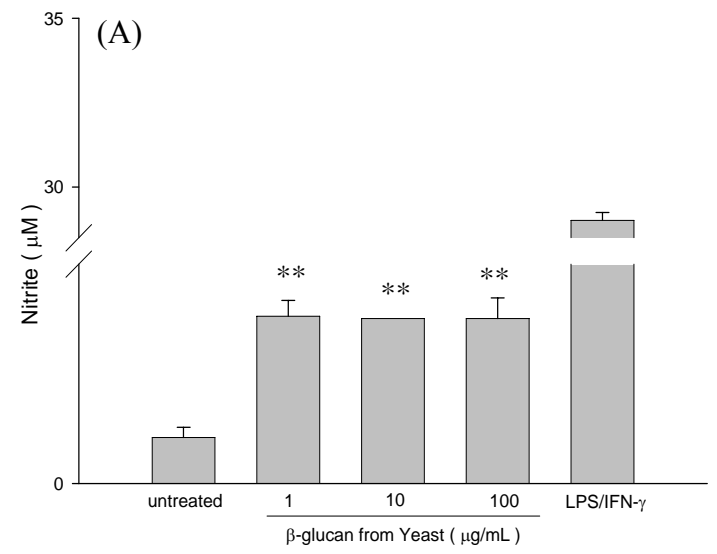

(D) $\quad \beta$-glucan from Bacteria $(\mu \mathrm{g} / \mathrm{mL})$
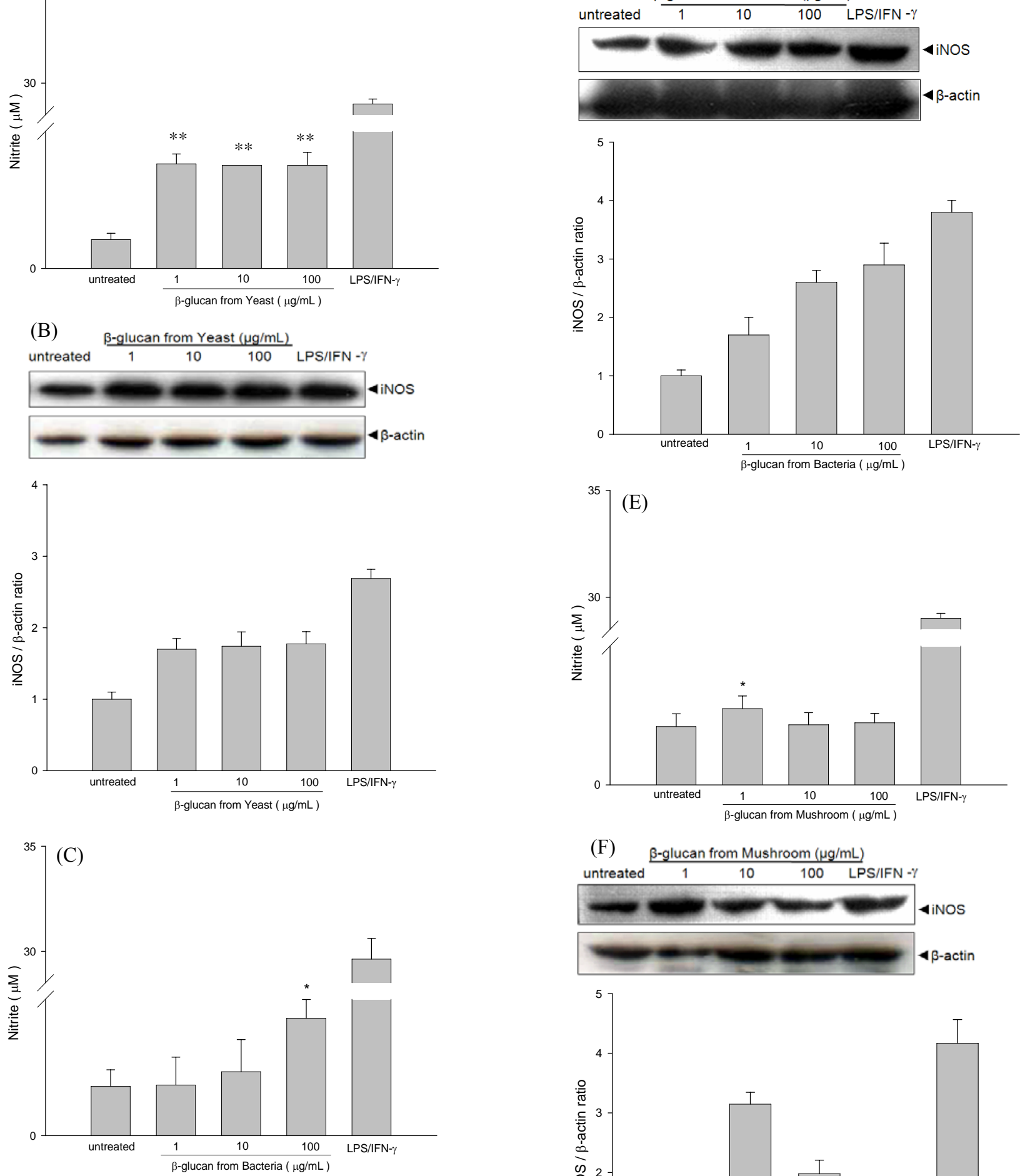

(F) ß-glucan from Mushroom $(\mu \mathrm{g} / \mathrm{mL})$

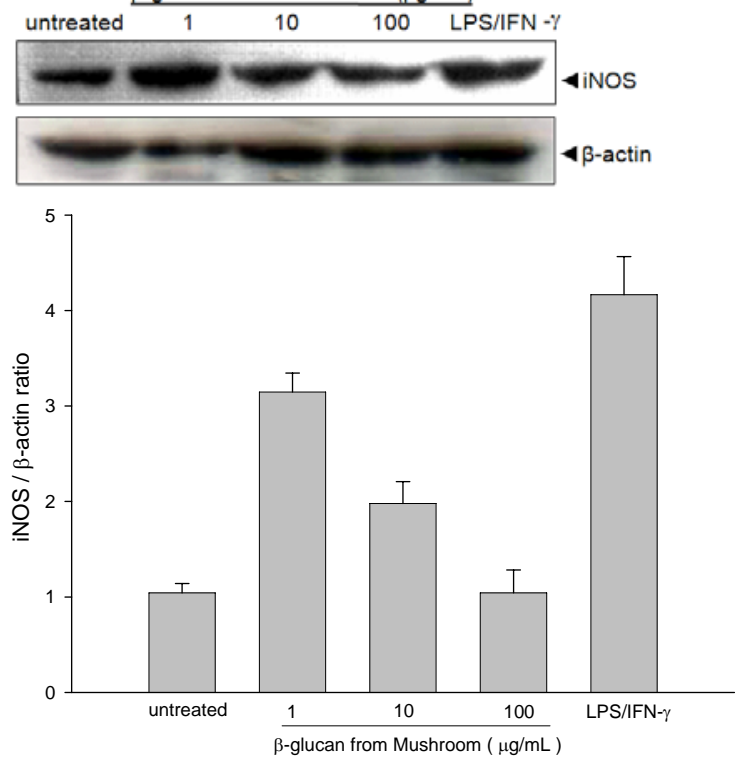

Fig. 3. The effects of $\beta$-glucans from yeast $(A, B)$, bacteria $(C, D)$, and mushrooms $(\mathrm{E}, \mathrm{F})$ on the production of nitrite and iNOS gene expression in RAW264.7 cells. The cells $\left(1 \times 10^{4}\right.$ cells/well $)$ were treated with various concentrations of the three types of $\beta$-glucans for $24 \mathrm{hr}$. Culture supernatants were collected and the levels of nitrite were measured as described in the Materials and Methods. The data represent the mean \pm SEM of quadruplicate experiments. ${ }^{*} \mathrm{p}<0.05,{ }^{* *} \mathrm{p}<0.01$; significantly different from the control (no treatment). The RAW264.7 cells were treated with two reagents for $24 \mathrm{hr}$. Total protein was extracted and subjected to Western blot analysis for iNOS and $\beta$-actin genes. 
Mushroom $\beta$-glucans have short $\beta(1,6)$-linked branches coming off of the $\beta(1,3)$ backbone. Yeast $\beta$-glucans have $\beta(1,6)$ branches that are further elaborated with additional $\beta(1,3)$ regions $(20)$. These secondary structures confer the biological functions of $\beta$-glucans on immune activities, by allowing interaction with their corresponsive receptors on cell surfaces. Each fragmented component binds to different $\beta$-glucan receptors, and the binding between receptors on macrophage surfaces is responsible for stimulating the immune system.

Several macrophage receptors are reported to recognize and bind $\beta$-glucans. For example, monocyte/macrophage scavenger receptors (SRs) and Dectin-1 were reported to bind $\beta$-glucan $(21,22)$. Also, TLR4 is important in mediating responses to mushroom-derived polysaccharide-protein complexes, as this receptor was found to be required for macrophage activation by glycoproteins isolated from Ganoderma lucidum and Poria cocus (23-25). Vereschagin et al. (21) extended this observation by demonstrating that $\beta$-glucan interactions with macrophage SRs protects against endotoxic shock. This suggests that macrophage SRs may be involved in $\beta$-glucan recognition and signaling. Rice et al. reported that human monocyte SRs recognize and interact with $(1 \rightarrow 3)$ - $\beta$-D-glucan polymers. The interaction of $\beta$ -glucans and SRs is influenced by polymer structure, polymer charge, and other undefined parameters (26). Herre et al. showed that Dectin-1 mediates the internalization of $\beta$-glucan bearing ligands, including yeast particles (27). Even though several $\beta$-glucan receptors are known to recognize the basic $\beta$-glucan structure, detailed structural determinants and other influencing factors in the $\beta$-glucan-recpetor interaction remain to be defined. A comparison of our results with those of other researchers suggests that different glucan sources may differ in their degree of heterogeneity and that the major $\beta-(1 \rightarrow 3)$-glucan component may vary considerably in its degree of branching and interaction with proper receptors. Therefore, the binding of $\beta$-glucans to their specific receptors can elicit a serial cellular response by modulating the activities of various factors including cytokines, chemokines, transcriptional factors, and growth factors (18).

In activated macrophages, there is a high level of NO produced by induced iNOS and this high amount of NO mediates the anti-bacterial and tumoricidal actions of macrophages. Thus, an increase in NO production can result in enhanced tumoricidal activity. In our study, it was shown that the different $\beta$-glucans stimulated tumoricidal activity as well as the NO-iNOS activation system; however, there seemed to be no consistent correlations between the tumoricidal and NO-iNOS activation effects of the $\beta$-glucans, suggesting that tumoricidal activity is not tightly associated with the NO-iNOS activation system. Therefore, we did not exclude the possibility that other mediators such as TNF- $\alpha$ and reactive oxygen intermediates are involved in the stimulatory effects of various $\beta$-glucans on tumoricidal activity.

It is unclear why a high concentration of bacterial $\beta$ glucans resulted in reductions of phagocytotic and tumoricidal activity. It is plausible that the cells became desensitized by the high concentration of $\beta$-glucans, subsequently causing the modification of receptor molecules. In previous studies we found that $\beta$-glucans from C. versicolor increased SR-A1 expression at 1 and 10 $\mu \mathrm{g} / \mathrm{mL}$, whereas at $100 \mu \mathrm{g} / \mathrm{mL}$ they decreased SR-A1 expression (data not shown, in press). Thus, $\beta$-glucan treatments at high concentrations might decrease the expression of certain receptors, and then also decrease the $\beta$-glucan signal.

In conclusion, which might be applied to different types of diseases in clinical situations.

\section{REFERENCES}

1. Williams DL, Pretus HA, Browder IW. 1992. Application of aqueous gel permeation chromatography with in-line multi-angle laser light scattering and differential viscometry detectors for the characterization of natural product carbohydrate pharmaceuticals. J Liq Chromatogr 15: 2297-2309.

2. Muller A, Rice PJ, Ensley HE, Coogan PS, Kalbfleisch JH, Kelley JL, Love EJ, Portera CA, Ha T, Browder IW, Williams DL. 1996. Receptor binding and internalization of water-soluble $(1 \rightarrow 3)$-beta-D-glucan biologic response modifier in two monocyte/macrophage cell lines. $J$ Immunol 156: 3418-3425.

3. Williams DL, Mueller A, Browder W. 1996. Glucan-based macrophage stimulators: a review of their anti-infective potential. Clin Immunother 5: 392-399.

4. Yadomae T. 2000. Structure and biological activities of fungal $\beta$-1,3-glucans. Yakugaku Zasshi 120: 413-431.

5. Di Luzio NR, Williams DL, McNamee RB, Edwards BF, Kitahama A. 1979. Comparative tumor-inhibitory and anti-bacterial activity of soluble and particulate glucan. Int J Cancer 24: 773-779.

6. Imura H, Ohno N, Suzuki I, Yadomae T. 1985. Purification, antitumor activity, and structural characterization of $\beta$-1,3-glucan from Peziza vesiculosa. Chem Pharm Bull 33: $5096-5099$.

7. Hahn H, Kaufmann SH. 1981. The role of cell-mediated immunity in bacterial infections. Rev Infect Dis 3: 1221-1250.

8. Verstovsek S, Maccubbin D, Mihich E. 1992. Tumoricidal activation of murine resident peritoneal macrohages by interleukin 2 and tumor necrosis factor. Cancer Res 52: 3880-3885.

9. Adams DO, Hamilton TA. 1984. The cell biology of macrophage activation. Annu Rev Immunol 2: 283-318. 
10. Burleson GR, Dean JH, Munson AE. 1995. Introduction to the mononuclear phagocyte system. In Methods in immunotoxicology. Wiley-Liss, New York. Vol 2, p 3-13.

11. Nathan CF. 1987. Secretory products of macrophages. $J$ Clin Invest 79: 319-326.

12. Fidler IJ, Kleinerman ES. 1983. Therapy of cancer metastasis by systemic activation of macrophages: from the bench to the clinic. Res Immuno 144: 284-287.

13. Keller R, Keist R. 1989. Abilities of activated macrophages to manifest tumoricidal activity and to generate reactive nitrogen intermediates: a comparative study in vitro and ex vivo. Biochem Biophys Res Commun 164: 968-973.

14. Bredt DS, Snyder SH. 1994. Nitric oxide: a physiologic messenger molecule. Annu Rev Biochem 63: 175-195.

15. Mosmann T. 1983. Rapid colorimetric assay for cellular growth and survival: application to proliferation and cytotoxicity assays. J Immunol Methods 65: 55-63.

16. Okimura T, Ogawa M, Yamauchi T. 1986. Stress and immune responses. III. Effect of resistant stress on delayed type hypersensitivity (DTH) response, natural killer (NK) activity and phagocytosis in mice. Jpn J Pharmacol 41: 229-235.

17. Ding AH, Nathan CF, Stuehr DJ. 1988. Release of reactive nitrogen intermediates and reactive oxygen intermediates from mouse peritoneal macrophages. Comparison of activating cytokines and evidence for independent production. J Immunol 141: 2407-2412.

18. Akramiene D, Kondrotas A, Didziapetriene J, Kevelaitis E. 2007. Effects of beta-glucans on the immune system. Medicina (Kaunas) 43: 597-606.

19. Chen J, Seviour R. 2007. Medicinal importance of fungal beta-( $1 \rightarrow 3),(1 \rightarrow 6)$-glucans. Mycol Res 111: 635-652.

20. Kuo YC, Huang YL, Chen CC, Lin YS, Chuang KN, Tsai WJ. 2002. Cell cycle progression and cytokine gene ex- pression of human peripheral blood mononuclear cells modulated by Agaricus blazei. J Lab Clin Med 140: 176-187.

21. Vereschagin EI, van Lambalgen AA, Dushkin MI, Schwartz YS, Polyakov L, Heemskerk A, Huisman E, Thijs LG, van den Bos GC. 1998. Soluble glucan protects against endotoxin shock in the rat: the role of the scavenger receptor. Shock 9: 193-198.

22. Taylor PR, Brown GD, Reid DM, Willment JA, Martinez-Pomares L, Gordon S. 2002. The $\beta$-glucan receptor, dectin- 1 , is predominantly expressed on the surface of cells of the monocyte/macrophage and neutrophil lineages. J Immunol 169: 3876-3882.

23. Shao BM, Xu W, Dai H, Tu P, Li Z, Gao XM. 2004. A study on the immune receptors for polysaccharides from the roots of Astragalus membranaceus, a Chinese medicinal herb. Biochem Biophys Res Commun 320: 1103-1111.

24. Hsu HY, Hua KF, Lin CC, Lin CH, Hsu J, Wong CH. 2004. Extract of reishi polysaccharides induces cytokine expression via TLR4-modulated protein kinase signaling pathways. J Immunol 173: 5989-5999.

25. Lee KY, You HJ, Jeong HG, Kang JS, Kim HM, Rhee SD, Jeon YJ. 2004. Polysaccharide isolated from Poria cocos sclerotium induces $\mathrm{NF}-\kappa \mathrm{B} / \mathrm{Rel}$ activation and iNOS expression through the activation of p38 kinase in murine macrophages. Int Immunopharmacol 4: 1029-1038.

26. Rice PJ, Kelley JL, Kogan G, Ensley HE, Kalbfleisch JH, Browder IW, Williams DL. 2002. Human monocyte scavenger receptors are pattern recognition receptors for $(1 \rightarrow$ 3)-beta-D-glucans. J Leukoc Biol 72: 140-146.

27. Herre J, Marshall AS, Caron E, Edwards AD, Williams DL, Schweighoffer E, Tybulewicz, V, Reise Sousa C, Gordon S, Brown GD. 2004. Dectin-1 uses novel mechanisms for yeast phagocytosis in macrophages. Blood 104: 4038-4045.

(Received April 9, 2009; Accepted June 16, 2009) 